\title{
Contextual Determinants of Alcohol Consumption Changes and Preventive Alcohol Policies: A 12-Country European Study in Progress
}

\author{
Allaman Allamani ${ }^{1}$, Fabio Voller ${ }^{1}$, Adriano Decarli ${ }^{1}$, Veronica Casotto ${ }^{1}$, Karin Pantzer ${ }^{1}$, \\ Peter Anderson ${ }^{2}$, Antoni Gual ${ }^{3}$, Silvia Matrai ${ }^{3}$, Zsuzsanna Elekes ${ }^{4}$, Irmgard Eisenbach-Stangl ${ }^{5}$, \\ Gabriele Schmied $^{5}$, Ronald A. Knibbe ${ }^{6}$, Sturla Nordlund ${ }^{7}, \varnothing y s t e i n ~ S k j æ l a a e{ }^{7}$, Börje \\ Olsson $^{8}$, Jenny Cisneros Örnberg ${ }^{8}$, Esa Österberg ${ }^{9}$, Thomas Karlsson ${ }^{9}$, Martin Plant ${ }^{10}$, \\ Moira Plant ${ }^{10}$, Patrick Miller ${ }^{10}$, Nikki Coghill ${ }^{10}$, Grażyna Świątkiewicz ${ }^{11}$, Lukasz Wieczorek ${ }^{11}$, \\ Beatrice Annaheim ${ }^{12}$ and Gerhard Gmel ${ }^{12}$ \\ ${ }^{1}$ Regione Toscana Health Agency, Florence, Italy; ${ }^{2}$ Faculty of Health, Medicine and Life Sciences, Maastricht \\ University, Maastricht, the Netherlands; ${ }^{3}$ Alcoholism Unit, Clinical Hospital Barcelona, Barcelona, Spain; ${ }^{4}$ Institute of \\ Sociology and Social Policy, Corvinus University of Budapest, Budapest, Hungary; ${ }^{5}$ European Centre for Social \\ Welfare Policy and Research, Vienna, Austria; ${ }^{6}$ Department of Health Promotion, Faculty of Health, Medical, and Life \\ Sciences, University of Maastricht, Maastricht, the Netherlands; ${ }^{7}$ Norwegian Institute for Alcohol \& Drug Research, \\ Oslo, Norway; ${ }^{8}$ SoRAD, Stockholm University, Stockholm, Sweden; ${ }^{9}$ National Institute for Health and Welfare (THL), \\ Helsinki, Finland; ${ }^{10}$ Alcohol \& Health Research Unit, University of the West of England, Bristol, UK; ${ }^{11}$ Institute of \\ Psychiatry and Neurology, Warsaw, Poland; ${ }^{12}$ Addiction Info Switzerland, Lausanne, Switzerland
}

Beginning with France in the 1950s, alcohol consumption has decreased in Southern European countries with few or no preventive alcohol policy measures being implemented, while alcohol consumption has been increasing in Northern European countries where historically more restrictive alcohol control policies were in place, even though more recently they were loosened. At the same time, Central and Eastern Europe have shown an intermediate behavior. We propose that country-specific changes in alcohol consumption between 1960 and 2008 are explained by a combination of a number of factors: (1) preventive alcohol policies and (2) social, cultural, economic, and demographic determinants. This article describes the methodology of a research study designed to understand the complex interactions that have occurred throughout Europe over the past five decades. These include changes in alcohol consumption, drinking patterns and alcoholrelated harm, and the actual determinants of such changes.

Keywords alcohol consumption, sociocultural determinants, demographics, alcohol policy, time trend

Among others, thanks to the late Eva Buiatti for her great support and scientific cooperation, and to Harold Holder for his suggestions. The research leading to these results has received funding from the European Community's Seventh Framework Program (FP7/2007-2013) under grant agreement no. 223059-Alcohol Measures for Public Health Research Alliance (AMPHORA). Partners in AMPHORA are: (1) Coordination: Hospital Clínic de Barcelona (HCB), Spain; (2) Agenzia Regionale di Sanità della Toscana (ARS), Italy; (3) Alcohol \& Health Research Unit, University of the West of England, UK; (4) Anderson, Consultant in Public Health, Spain; (5) Anton Proksch Institut (API), Austria; (6) Azienda Sanitaria Locale della Città di Milano (ASL MILANO), Italy; (7) Budapesti Corvinus Egyetem (BCE), Hungary; (8) Central Institute of Mental Health (CIMH), Germany; (9) Centre for Applied Psychology, Social and Environmental Research (ZEUS), Germany; (10) Chemisches und Veterinäruntersuchungsamt Karlsruhe Technische Universität (CVUAKA), Germany; (11) Dutch Institute for Alcohol Policy (STAP), Netherlands; (12) Eclectica snc di Amici Silvia Ines, Beccaria Franca \& C. (ECLECTICA), Italy; (13) European Centre for Social Welfare Policy and Research (ECV), Austria; (14) Generalitat de Cataluña (Gencat), Spain; (15) Institute of Psychiatry and Neurology (IPIN), Poland; (16) Institute of Psychiatry, King's College London (KCL), UK; (17) Istituto Superiore di Sanità (ISS), Rome, Italy; (18) Inštitut za raziskave in razvoj (UTRIP), Slovenia; (19) IREFREA, Spain; (20) Liverpool John Moores University (LJMU), UK; (21) National Institute for Health and Welfare (THL), Finland; (22) Nordiskt välfärdscenter (NVC), Finland; (23) Norwegian Institute for Alcohol and Drug Research (SIRUS), Norway; (24) State Agency for Prevention of Alcohol-Related Problems (PARPA), Poland; (25) Stockholms Universitet (SU), Sweden; (26) Swiss Institute for the Prevention of Alcohol and Drug Problems (SIPA), Switzerland; (27) Technische Universität Dresden (TUD), Germany; (28) Trimbos-instituut (TRIMBOS), Netherlands; (29) University of Bergen (UiB), Norway; (30) Universiteit Twente (UT), Netherlands; (31) University Maastricht (UM), Netherlands; (32) University of York (UoY), UK.

Address correspondence to Allaman Allamani, Via P. Toselli, 140, 50144 Firenze, Italia; E-mail: allamana@gmail.com. 


\section{INTRODUCTION}

\section{Drinking Trends in Europe Over the Last Five Decades}

Europe is a complex, cultural, social, political, and economical entity. With regard to alcoholic beverages, Europe has a long history of diverse traditions and values concerning drinking culture, alcohol-consumption-related harms, and prevention policies. Europe is the heaviest drinking region in the world (Anderson \& Baumberg, 2005; Heath, 1995; Heather, 2006; Olsson, Olafsdottir, \& Room, 2002a; Österberg \& Karlsson, 2002a; Plant \& Plant, 2006; Rehm et al., 2003; Room, 2002a; Room \& Mäkelä, 2000).

From the 1960s, alcohol consumption has undergone several changes in Europe. In the northern countries, there has been a general increase in consumption. The most evident being in Finland where in 1955 the per capita alcohol consumption was recorded as 1.97 liters while by 2005 the per capita figures had increased to 8.23 liters. There has been a decrease in consumption, particularly regarding wine, in the Mediterranean countries. For example, in Italy, the consumption of alcohol decreased from 13.07 liters of recorded alcohol per capita in 1970 to 6.9 liters in 2005. Central and Eastern Europe have also experienced some changes (Leifman, 2001; Productshap Voor Gedistillerde Dranken, 2005). A partial convergence of drinking patterns occurred more recently, especially among adolescents (Currie et al., 2004; Hibell et al., 2009).

Alcohol consumption is one of the most important health determinants throughout Europe. There have been notable changes, as an example, in both the incidence and prevalence over the past five decades of alcoholconsumption-related liver diseases (Edwards et al., 1994). In the 1970s and earlier, this was particularly notable throughout the traditional North-South gradient, with Southern European countries manifesting a five to six times greater incidence of mortality from liver cirrhosis compared with Northern European countries (Ramstedt, 2002). These differences have narrowed over time, which may be associated with the convergence of alcohol consumption between the two regions.

\section{Preventive Alcohol Policies in Europe Over the Last Five Decades: A Complex Approach}

Preventive alcohol consumption policy, which is usually briefly defined as alcohol policy, addresses the consumption of alcohol beverages and their related harm. Alcohol policy measures, which are planned by the national as well as local governments to control the supply and demand of alcoholic beverages, aim at minimizing alcoholconsumption-related problems and promoting social well-being among the general population. Such measures consist of different methods including price and tax policy, regulation and restriction of alcohol availability, accessibility and opportunities to drink, advertising regulations, education and information programs, control of public drinking and of drunk driving, and preventive actions aimed to mobilize communities (Bruun et al., 1975; Grant, 1985; Mäkelä, Room, Singel, Sulkunen, \&
Walsh, 1981; Österberg \& Karlsson, 2002b; World Health Organozation [WHO], 1992). Another group of policies that are directed to individual drinkers at risk includes brief intervention programs, treatment, and rehabilitation.

Generally, policy-makers and politicians have made policy changes without acknowledging or even taking into account research findings (Room, 2002a). Nonetheless, the effectiveness of alcohol consumption policies in controlling the consumption of alcoholic beverages and alcohol-consumption-related harm does have a wellestablished evidence base (Babor et al., 2003; Holder et al., 2000; Holmila, 1997; Norström, 2002; Pridemore \& Snowden, 2009; Rehm et al., 2003; Wagenaar, 1986). Existing infrastructures within a country's health sector are a crucial element in implementing preventive alcohol policy programs (König \& Segura, 2011).

One problem that interferes with the development of policies and their effectiveness is the perceptions of the alcohol beverages and the drinking patterns in each country and how well-integrated alcohol and its associated functions are within the culture. If alcohol consumption and misuse are seen primarily as a social and health problem, alcohol policies may be accepted as being useful. In countries where alcohol is more integrated into the culture, the same policies may get little attention or support (Room, 1999). Moreover, at least in the latter societies, government measures sometimes appear to be more of a popular and symbolic nature than as a response to the real needs of the population. Finally, the enforcement of measures and their interplay with informal control varies according to nations, cultures, and temporal periods (Österberg $\&$ Karlsson, 2002). The most consistent measures of the impact of alcohol policies remain as changes in alcohol consumption within and between different countries (Österberg \& Karlsson, 2002b).

The effectiveness of policy measures appears to vary across countries, and at a first glance, it does not simply relate to the policy measures themselves. Sometimes reduction in consumption occurs without any alcohol consumption policy in place, or conversely increase in consumption occurs in spite of preventive measures.

Alcohol policy has an old Nordic history (Olsson et al., 2002). During the last century, the policies of Nordic countries were based on the restriction strategy of high taxes, age limits, regulations of advertising and licensing, and comprehensive state alcohol monopolies (Österberg \& Karlsson, 2002a). Nonetheless, there has been an increase in consumption of alcoholic beverages in the Nordic countries, even though their policies are still the most comprehensive and strict in Europe (Österberg \& Karlsson, 2002b). Major factors of this increase have often been identified in the weakening of the Nordic model, or in the relative dismantling of the traditional alcohol control system due to domestic pressures and the "single market ideology" of the European Union (Holder et al., 1998; Norström, 2002; Room, 2002b; Room, Babor, \& Rehm, 2005; Sulkunen, Sutton, Tigerstedt, \& Warpenius, 2000). Doubts have been raised by some authors regarding the relevance of entering the European 


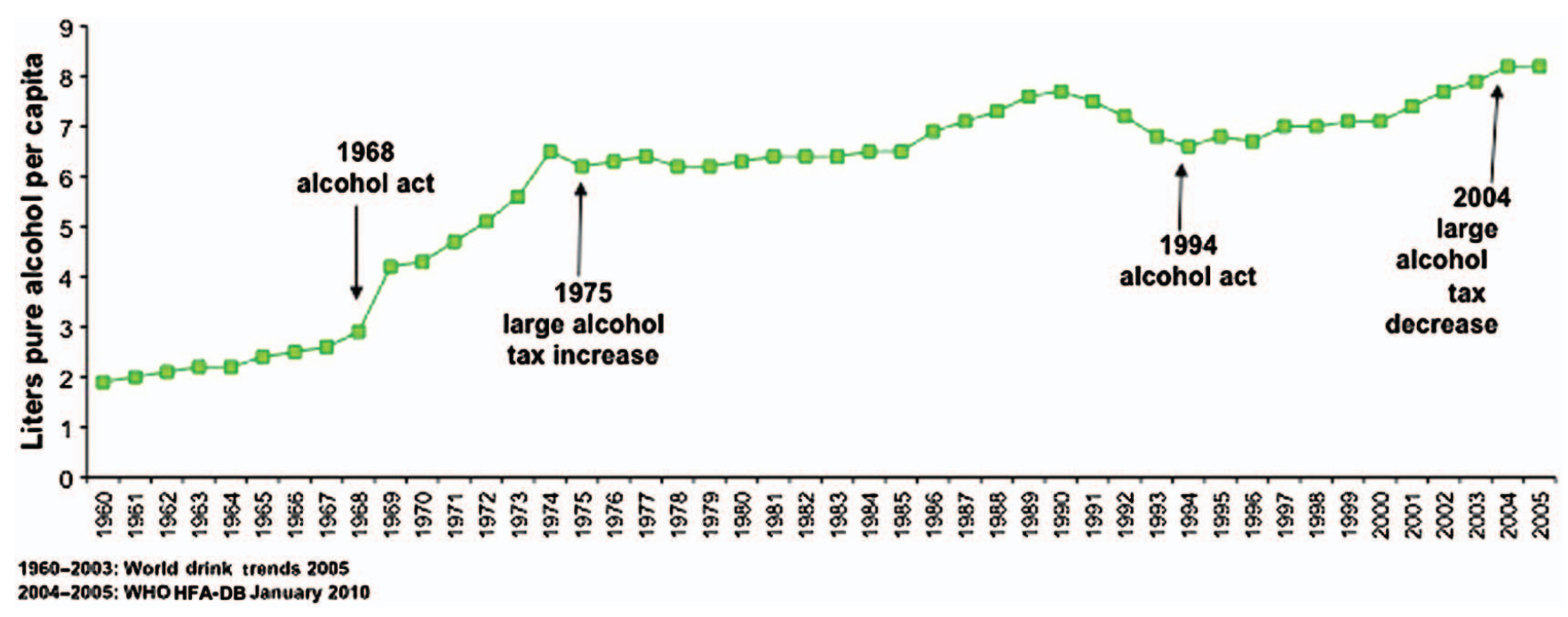

FIGURE 1. Recorded alcohol consumption trends in Finland and main policy measure changes (1960-2005).

Union in the 1990s as the reason for the increase in consumption (Holder, 2000). For example, in Finland, the 1968 Alcohol Act brought changes that included an increase of the availability of medium strength beer, the lowering of the age limits for buying alcoholic beverages, and the opening of monopoly liquor stores in the previously dry countryside. During the following years, the per capita alcohol consumption increased by more than $200 \%$ (Figure 1). In 1994, a Finnish Alcohol Act was introduced that repealed the alcohol monopolies on production, import, export, and wholesale, but left the monopoly on offpremise retail sale of alcoholic beverages almost intact (Karlsson \& Östenberg, 2002). This change may have had a smaller effect on Finnish alcohol consumption.

Nonetheless, the remarkable increase in consumption in Britain since the 1960s-from 5.86 liters of pure alcohol per capita in 1963 to 11.39 liters in 2006 - could in part be ascribed to a more liberal attitude of the governments (Plant \& Plant, 2006; WHO, 2009).

Among the Eastern European countries, alcohol consumption in Poland started to increase during the 1960s, reaching a peak by the end of the 1970s. This happened even though an "Act against alcoholism" (including many limitation for alcohol availability) had been approved by the parliament in 1958 (Österberg \& Karlsson, 2002b). A reduction of alcohol consumption in Poland, which occurred during the 1980s, might have been induced by the preventive measures implemented during that decade. More recent increases in consumption may be attributable to the new trend toward a market economy and liberalization that started in the 1990s (Moskalewicz \& Simpura, 2000).

Among the Southern European countries, formal policies are a recent introduction, compared with Northern Europe. They have been only partially or even hardly enforced, reflecting the weak position of their governments on this issue (Norström, 2002). Nonetheless, starting from the 1950s in France, and from the 1970s in countries like Italy and Spain, alcohol consumption has remarkably de- creased despite the fact that the first preventive policy measures were introduced in these countries only in the late 1980s, at most supporting the already existing descending trends. In Italy, the first post-World War II alcohol policy act was a law approved by the parliament in August 1988, introducing limits for drinking and driving (Allamani et al., 2002). This made it illegal to drive with a blood alcohol concentration (BAC) of 0.8 grams/liter or more (Figure 2).

Initially, the decreasing trend of alcohol consumption in the Mediterranean countries was not easily understood by researchers; expressions like "impossible dream" (Room, 1992) and "Mediterranean Mysteries" (Simpura, 1998) became a sort of explanatory image of South European drinking trends. Two studies, one about drinking in France in the 1960s-1970s (Sulkunen, 1989), and the other covering the drinking trends in Italy from 1970s to 2000s (Allamani \& Prina, 2007; Cipriani, 2007; Cipriani \& Tusini, 2007; Tusini, 2007), tried to shed some light on this. The authors concluded that change determinants such as urbanization, industrialization, the increased income in the 1970s, changes in the role of women, and increased health awareness in the 1980s-1990s for Italy were relevant factors. They appeared to have been more relevant to the reduction of alcohol (mainly wine) consumption than the preventive alcohol consumption policies.

Other research focused on additional factors that can affect drinking amount and pattern, even if not specifically intended to contribute to a health prevention policy such as market forces and economic interests of industries (Gual \& Colom, 1997), consumerism (Österberg \& Karlsson, 2002b), globalization of drinking practices (Hupkens, Knibbe, \& Drop, 1993; Knibbe, Drop, \& Hupkens, 1996), cross-border import of alcoholic beverages (Holder, 2009), immigration from nonEuropean countries with different cultures and religions (Admunsen, Rossow, \& Skurtveit, 2005; Allamani, Innocenti, Innocenti, Cipriani, \& Voller, 2009); Michalak, Trocki, \& Bond, 2007, income (Simpura, Karlsson, 


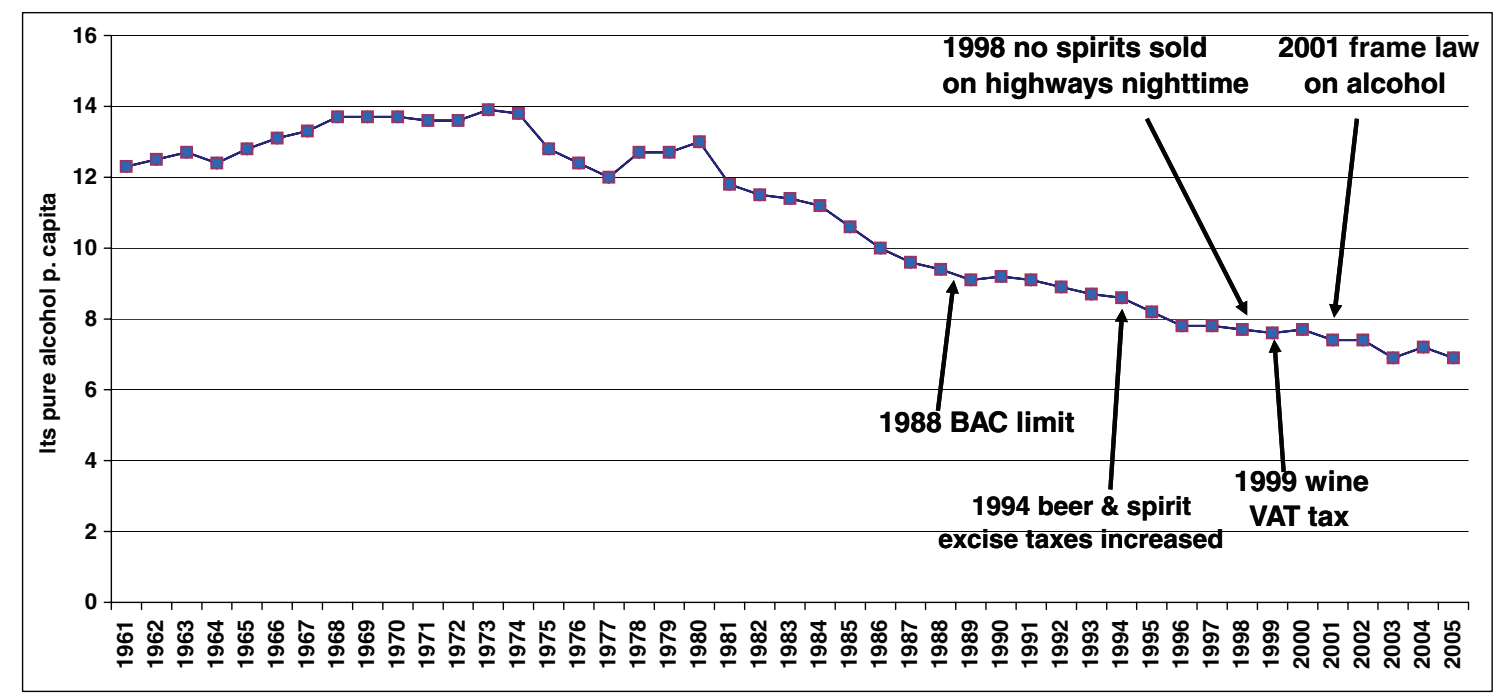

1960-2003: World Drink Trends 2005 2004 - 2005: WHO HFA-DB 2010

FIGURE 2. Recorded alcohol consumption trends in Italy and main policy measure changes (1960-2005).

\& Leppänen, 2002), and major national or regional sociopolitical changes (Holder et al., 1998; Moskalewicz \& Simpura, 2000).

The above-mentioned arguments do not mean that evidence-based preventive measures are not effective, but they indicate that alcohol prevention policies alone are not sufficient to explain changes in alcohol use over time. Indeed, the change in alcohol consumption over time is not a linear phenomenon, but rather the result of a complex interplay between an individual's use of alcohol beverages and the surrounding physical, economical, and cultural environment, as well as the social and political context. To better understand how and under which circumstances alcohol policies may, or may not, work, it is of the utmost importance to take into account the unplanned and uncontrolled variables at the time when policy actions are being planned. ${ }^{1}$

Policy and prevention research is particularly active in English-speaking and Northern European societies (Room et al., 2005) but is less active in Southern and Eastern Europe countries (Anderson \& Baumberg, 2005; Craplet, 2006). This needs to be taken into consideration when planning a multicountry study.

\footnotetext{
${ }^{1}$ With the advent of artificial science and its theoretical underpinnings (chaos, complexity, and uncertainty theories), it is now posited that much of human behavior is complex, dynamic, multidimensional, level/phase structured, nonlinear, law-driven, and bounded (culture, time, place, age, gender, ethnicity, etc.). Alcohol consumption and policies designed to effect it would be such behaviors/processes. There are two important issues to consider and that are derived from this: (1) using linear models/tools to study nonlinear processes/phenomena can and does result in misleading conclusions and can therefore also result in inappropriate intervention; and (2) the concepts of prediction and control have different meanings and dimensions than they do in the more traditional linear "cause and effect" paradigms (Editor's note).
}

In order to explore the above aspects, the authors have designed a project, which started in 2009. This article describes the aims and methods used in this project.

\section{THE STUDY}

The study focuses on the period 1960-2008 and is being conducted between 2009 and 2012. It includes 12 countries from Central, Eastern, Northern, Southern, and Western Europe, including Austria, Finland, France, Hungary, Italy, Netherlands, Norway, Poland, Spain, Sweden, Switzerland, and the United Kingdom. These countries have different, or quite different, geographical, cultural, social, economical, and political aspects. As to the values and practices attributed to alcoholic beverages, they are grouped in Table 1, according to a geographical classification.

This geographical classification is also a cultural classification, because each country as well as each group of countries can be identified with a drinking culture. However, in each country, there may also be many drinking subcultures. Also, the distinction among country's drinking cultures has been weakening over time, as it is shown in the previous sections. Nonetheless, the country/cultural equivalence has still the advantage of both retaining a relative clarity and not increasing the number of variables to be studied at the level of analysis.

\section{Aim}

This study is based on the premise that the preventive alcohol consumption policies alone do not cause nor explain changes in alcohol consumption, drinking patterns, and alcohol-consumption-related harm. These changes can only be explained when other contextual factors such as social, cultural, economic, religious, demographic, and 
TABLE 1. European countries involved in the study

\begin{tabular}{lllll}
\hline Northern countries & Central countries & Western countries & Eastern countries & Southern countries \\
\hline Sweden & Austria & UK & Hungary & France \\
Norway & Switzerland & Netherlands & Poland & Spain \\
Finland & & & Italy \\
\hline
\end{tabular}

"big events"2 factors are considered simultaneously. This broader perspective, incorporating the contextual determinants of changes, and their interrelationships, with regard to consumption, must be considered in order to identify the most effective and cost-effective consumption prevention policies aimed at reducing the consequent alcoholconsumption-related harm. These considerations would enable appropriate policies to be adapted for each country.

Therefore, this study aims to identify changes in the contextual factors that are most strongly correlated with changes in alcohol consumption, drinking patterns, and related harm between 1960 and 2008 throughout the 12 countries in Europe. ${ }^{3}$ Changes in alcohol prevention policies over the same time period in the same countries will also be considered.

\section{Variables}

Both dependent and independent variables are detailed as follows.

Dependent variables:

- alcohol consumption and drinking patterns,

- alcohol-consumption-related harm.

Independent variables:

- alcohol consumption policy measures, planned by governments to control consumption and drinking patterns, and alcohol-consumption-related harm;

- the unplanned determinants of consumption changes, i.e., a number of social, cultural, economic, and demographic factors that are not planned by governments and health authorities, but that may affect consumption, drinking patterns, and alcohol-consumptionrelated harm.

Alcohol Consumption and Drinking Patterns. Data available from 1960 to 2008 for each European country on per capita alcohol consumption in those aged 15 years and older are provided. When considering data across countries, comparison sources can be adopted from the WHOEURO Health for All Database and the WHO Global

\footnotetext{
${ }^{2}$ This relatively new term, introduced into the intervention literature, refers to major events such as mega disasters, natural as well as manmade, famine, conflict, genocide, disparities in health, epidemics, mass migrations, economic recessions, etc., which effect adaptation, functioning, and quality-of-life of individuals as well as systems. Existential threat, instability, and chaos are major dimensions and the loss of control over one's life is experienced (Editor's note).

${ }^{3}$ Refer to Hills's criteria for causation that were developed in order to help assist researchers and clinicians determine if risk factors were causes of a particular disease or outcomes or merely associated (Hill, 1965) (Editor's note).
}

Information System on Alcohol and Health (GISAH; Anderson \& Baumberg, 2005; Rehm \& Scafato, 2011).

The concept of drinking pattern encompasses many different characteristics. These include gender- and agespecific preferences for different recorded and unrecorded types of alcoholic beverages; the frequency of drinking, such as daily or weekends only, binge drinking, and the drinking context; with or without meals; with family, friends, or alone; and at home, in bars, pubs, or restaurants. Although some information is available within each country, there is a lack of studies that are comparable over time at the European level (Simpura et al., 2002), despite the attempts in WHO's Global Burden of Disease study (Anderson \& Baumberg, 2005). Nonetheless, the European Comparative Alcohol Study (ECAS) study (Norström, 2002) and Eurobarometer (Hupkens et al., 1993) are able to give information concerning a few European countries for a limited time period. There are few European studies that have investigated the levels of unrecorded alcohol consumption (Leifman, 2002).

Detrimental Alcohol-Consumption-Related Consequences. Mortality for liver cirrhosis is a traditional indicator of a chronic consequence of alcohol consumption (Edwards et al., 1994). The number of persons killed or harmed in road traffic injuries can be considered as an acute indicator of alcohol-consumption-related harm. Comparable sources for the European region are in the WHO's Global Status Report on Alcohol and the WHO Global Burden of Disease Study (Rehm \& Scafato, 2011).

Planned Determinants: Alcohol Policy Measures. Alcohol preventive policies such as legislation regarding alcohol, increasing taxes, or age limits, among others, are usually interrupted measures - in terms of a time series analysis defining a step function. Additionally, they tend to be introduced after a political or administrative decision or under pressure from communities or lobbyists. A recent WHO document reports the evidences for the effectiveness of different interventions meant to reduce alcoholrelated harm (Anderson, 2009). However, there is a need to better understand how and when the impact of the intervention occurs.

A list of usual preventive alcohol measures and of major preventive programs at the national level was selected and operationalized by the authors of this article. Table 2 describes the eight main factors associated with policies together with the corresponding indicator and operationalization, as well as its relevant references. Consequently, data are collected for each factor. An indicator is either "common" for all the participating countries, or only available to a few countries and labeled "country level." The latter will not be completely comparable 
TABLE 2. Variables related to the determinants of planned alcohol consumption changes (preventive alcohol policies)

\begin{tabular}{|c|c|c|}
\hline Variable & Indicator & Operationalization \\
\hline Price control (Anderson, 2009; Babor et al., 2003) & Taxes & $\begin{array}{l}\text { (1) List of major changes of excise duty on beer, } \\
\text { wine, spirit, by year } \\
\text { (2) List of major changes of VAT taxes on beer, } \\
\text { wine, spirit by year common }\end{array}$ \\
\hline $\begin{array}{l}\text { Advertising control (Anderson, 2009; Babor } \\
\text { et al., 2003) }\end{array}$ & Advertising limits & $\begin{array}{l}\text { List of major regulation and law changes over time, } \\
\text { by year, relating to: TV, radio, newspapers, sport } \\
\text { common }\end{array}$ \\
\hline Availability (Anderson, 2009; Babor et al., 2003; & Minimum age to buy alcohol & List of law changes over time, by year country level \\
\hline Österberg \& Karlsson, 2002a) & $\begin{array}{l}\text { Licensing rules for different } \\
\text { types of selling places } \\
\text { Trading hours }\end{array}$ & $\begin{array}{l}\text { List of major licensing changes over time, by year } \\
\text { country level } \\
\text { List of major changes in specific regulations for } \\
\text { on-licensed premises selling alcoholic beverages } \\
\text { over time, by year country level }\end{array}$ \\
\hline $\begin{array}{l}\text { Drink driving (Anderson, 2009; Babor et al., } \\
\text { 2003) }\end{array}$ & BAC limit & $\begin{array}{l}\text { List of BAC limit law changes over time, by year } \\
\text { common }\end{array}$ \\
\hline National Prevention Plan (Babor et al., 2003) & Nationwide prevention plans & $\begin{array}{l}\text { List of major nationwide prevention plan(s) and } \\
\text { strategies over time, by year country level }\end{array}$ \\
\hline Enforcement (Österberg \& Karlsson, 2002b) & Not enforcing laws/regulations & Qualitative description by country country level \\
\hline $\begin{array}{l}\text { Education (Anderson, 2009; Babor et al., 2003; } \\
\text { Österberg \& Karlsson, 2002b) }\end{array}$ & Nationwide education programs & $\begin{array}{l}\text { List of major nationwide educational campaigns, by } \\
\text { year country level }\end{array}$ \\
\hline $\begin{array}{l}\text { Community projects (Anderson, 2009; Babor } \\
\text { et al., 2003) }\end{array}$ & Relevant community projects & $\begin{array}{l}\text { List of major community project, by year country } \\
\text { level }\end{array}$ \\
\hline $\begin{array}{l}\text { Development of health system programs treating } \\
\text { alcohol-consumption-related problems } \\
\text { (Anderson, 2009; Babor et al., 2003) }\end{array}$ & $\begin{array}{l}\text { Alcohol misuser treatment } \\
\text { programs }\end{array}$ & $\begin{array}{l}\text { List of major changes in alcohol treatment } \\
\text { program/organization, by year country level }\end{array}$ \\
\hline
\end{tabular}

Note: Common indicators are available for all the countries; country-level indicators are only available for 1 or few countries.

across all participating countries; therefore, at this level, each policy measure will be analyzed separately and will be part of a separate country report.

At a more comprehensive level, each country's alcohol policies, even when composed of different factors, should be evaluated taking into account its overall impact. Östenberg and Karlsson in the ECAS study have proposed a classification of European countries on the basis of the comprehensiveness and strictness of different alcohol consumption policies (Karlsson \& Österberg, 2001; Österberg \& Karlsson, 2002a), while other authors created an "Alcohol Policy Index" to gauge the strength of the alcohol control policies in 30 European and non-European countries (Brand, Saisana, Rynn, Pennoni, \& Lowenfels, 2007).

Unplanned Determinants of Alcohol Consumption Changes. A number of meetings were organized from 2006 to 2009 between the participating countries in order to identify the contextual and unplanned determinants. Drawing from the existing literature, the authors of this article discussed several indicators of determinants of potential, unplanned, alcohol consumption changes (Admunsen et al., 2005; Allamani \& Prina, 2007; Brand et al., 2007; Cipriani, 2007; Gruenewald, Remer, \& Lipton, 2002; Gual \& Colom, 1997; Holder, 2009; Hupkens et al., 1993; Karlsson \& Österberg, 2001; Knibbe et al., 1996; Michalak et al., 2007; Munro, 2004; Österberg \& Karlsson, 2002b; Sulkunen, 1989; Tusini, 2007; Tusini, 2007; Allamani et al., 2009). Sixteen main classes of unplanned demographic, economic, social, cultural, and health variables were identified, each with its indicator and operationalization and references (see Table 3). This gave a total of 37 unplanned indicators, which were thought to be able to catch the entire area of the unplanned determinants of consumption changes; they focused on health in one case, on culture in three cases, on social aspects in four cases, on economical aspects in 18 cases, and on demographic aspects in 11 cases. As previously discussed, an indicator may be supposed to be common to all countries, or be country specific if its data are available only for a few countries, or its definition has different meaning according to the countries (see Table 3). Some unplanned indicators, like an increase in the price of alcohol beverages, could be considered from a public health perspective as an "unintended alcohol policy, even if they may also be considered as an intended market policy introduced, for example, by the alcohol industry with regard to some brand of alcoholic beverage.

Indicators were chosen to capture the determinants that could either increase or decrease alcohol consumption. The same indicator may have different effect on different countries. For example, urbanization was associated with a decrease in alcohol consumption in Italy, while in Finland, this resulted in an increase in consumption. The study takes into account this type of differences.

Countries may also differ in the lag period needed for a change, in any determinant, to realize its full impact on the consumption of alcohol and the related harm. The lag time between a variable determinant and its effect can be taken into account by means of standard time series models 
TABLE 3. Variables related to the determinants of unplanned alcohol consumption changes (sociocultural, economic, and demographic)

\begin{tabular}{|c|c|c|}
\hline Variable & Indicator & Operationalization \\
\hline \multirow[t]{3}{*}{$\begin{array}{l}\text { Demographic issues (Cipriani \& Tusini, } \\
\text { 2007) }\end{array}$} & Rate of youngsters & $\begin{array}{l}\text { Number of people aged } 0-15,16-30 \text { years } / 100,000 \\
\text { total population, by gender common }\end{array}$ \\
\hline & Rate of elderly people & $\begin{array}{l}\text { Number of people aged } 65 \text { years and over/100,000 total } \\
\text { population common }\end{array}$ \\
\hline & Mean age & Mean age by gender common \\
\hline \multirow[t]{3}{*}{$\begin{array}{l}\text { Migration (Admunsen et al., 2005; } \\
\text { Sulkunen, 1989) }\end{array}$} & Migration inside the country & $\begin{array}{l}\text { Number of resident population in "small" (rural), } \\
\text { "medium," "large" (metropolitan) towns according to } \\
\text { country definition /100,000 total population country } \\
\text { level }\end{array}$ \\
\hline & $\begin{array}{l}\text { Migration inflows (immigration } \\
\text { from other countries) }\end{array}$ & $\begin{array}{l}\text { Number of people obtaining legal permanent resident } \\
\text { status by country of birth/100,000 total population } \\
\text { country level }\end{array}$ \\
\hline & $\begin{array}{l}\text { Migration outflows (emigration } \\
\text { to another country) }\end{array}$ & $\begin{array}{l}\text { Number of people defined as emigrants/100,000 total } \\
\text { population country level }\end{array}$ \\
\hline Education (Hupkens et al., 1993) & Educational level & $\begin{array}{l}\text { Number of people who have completed tertiary } \\
\text { education/100,000 total population by gender } \\
\text { country level }\end{array}$ \\
\hline \multirow[t]{2}{*}{ Employment (Tusini, 2007) } & Employment & $\begin{array}{l}\text { Number of employed people/100,000 total population } \\
\text { by gender country level }\end{array}$ \\
\hline & Employment by sector & $\begin{array}{l}\text { Number of employed people by sector (rural, } \\
\text { industrial, services)/100,000 total population by } \\
\text { gender country level }\end{array}$ \\
\hline \multirow[t]{2}{*}{ Income (Simpura et al., 2002) } & Income & Disposable income per household per year common \\
\hline & Inequality Index & $\begin{array}{l}\text { Gini coefficient (measure of inequality of income) } \\
\text { common }\end{array}$ \\
\hline \multirow[t]{5}{*}{$\begin{array}{l}\text { Changes in family and organization } \\
\text { (Leifman, 2002; Tusini, 2007) }\end{array}$} & Rate of employment & $\begin{array}{l}\text { Number of people employed/total labor force per 100, } \\
\text { by gender common }\end{array}$ \\
\hline & Age of women at first childbirth & Mean age of women at their first childbirth common \\
\hline & Rate of single parent households & $\begin{array}{l}\text { Number of single parent households by gender, in those } \\
\text { who are } 50 \text { years old or less } / 100,000 \text { total population } \\
\text { common }\end{array}$ \\
\hline & Rate of single person households & $\begin{array}{l}\text { Number of single person households by gender, in } \\
\text { those who are } 50 \text { years old or less/100,000 total } \\
\text { population common }\end{array}$ \\
\hline & Women having children & $\begin{array}{l}\text { Number of women under } 50 \text { having children/total } \\
\text { women under } 50 \times 100 \text { common }\end{array}$ \\
\hline \multirow[t]{6}{*}{$\begin{array}{l}\text { Market strategy (Gual \& Colom, 1997; } \\
\text { Tusini, 2007) }\end{array}$} & $\begin{array}{l}\text { Prices of different alcoholic } \\
\text { beverages }\end{array}$ & $\begin{array}{l}\text { Average prices per year of beer, wine, and spirits to be } \\
\text { separately indexed. Year } 1960 \text { is taken as } 1 \text { common }\end{array}$ \\
\hline & Expenditure on alcohol & $\begin{array}{l}\text { Per year household expenditure on alcohol } \\
\text { beverages/total household expenditure country level }\end{array}$ \\
\hline & \multirow[t]{2}{*}{ Price of food items } & $\begin{array}{l}\text { Average price per year of mineral water and soft drinks } \\
\text { to include fruit juices common }\end{array}$ \\
\hline & & $\begin{array}{l}\text { Average price of other foodstuffs such as bread, meat, } \\
\text { fish, milk, fruit, and vegetables country level }\end{array}$ \\
\hline & Alcohol advertising & $\begin{array}{l}\text { Expenditure for advertising alcoholic beverages /total } \\
\text { advertising expenditure country level }\end{array}$ \\
\hline & $\begin{array}{l}\text { Unintended counter-effects like } \\
\text { wine/methanol scandal }\end{array}$ & $\begin{array}{l}\text { Number of episodes of collective alcohol poisoning } \\
\text { country level }\end{array}$ \\
\hline $\begin{array}{l}\text { Alcohol industry (Gual \& Colom, 1997; } \\
\text { Munro, 2004) }\end{array}$ & $\begin{array}{l}\text { Influence on alcohol } \\
\text { consumption }\end{array}$ & $\begin{array}{l}\text { (Consider economic operators, interested groups) } \\
\text { country level }\end{array}$ \\
\hline $\begin{array}{l}\text { Food intake (Cipriani, 2007; Gual \& Colom, } \\
\text { 1997) }\end{array}$ & Trends in food consumption & $\begin{array}{l}\text { Consumption (liters per capita) per year of mineral } \\
\text { water, soft drinks, including fruit juices country level }\end{array}$ \\
\hline & & $\begin{array}{l}\text { Consumption (kilos per capita) per year of bread, meet, } \\
\text { fish, milk, fruit, and vegetables country level }\end{array}$ \\
\hline \multirow[t]{2}{*}{$\begin{array}{l}\text { Consumerism (Babor et al., 2003; } \\
\text { Gruenewald et al., 2002; Österberg \& } \\
\text { Karlsson, 2002a; Tusini, 2007) }\end{array}$} & $\begin{array}{l}\text { Income dedicated to purchasing } \\
\text { food and drink }\end{array}$ & $\begin{array}{l}\text { Household expenditure for food /total household } \\
\text { expenditure for nonfood items (included alcoholic } \\
\text { beverages) per year country level }\end{array}$ \\
\hline & $\begin{array}{l}\text { Density of on-licensed pubs, } \\
\text { restaurants, and pizzerias }\end{array}$ & $\begin{array}{l}\text { Numbers of on-licensed premises selling alcoholic } \\
\text { beverages } / 100,000 \text { total population common }\end{array}$ \\
\hline
\end{tabular}


TABLE 3. Variables related to the determinants of unplanned alcohol consumption changes (sociocultural, economic, and demographic) (Continued)

\begin{tabular}{|c|c|c|}
\hline Variable & Indicator & Operationalization \\
\hline & $\begin{array}{l}\text { Density of off-licensed pubs, } \\
\text { restaurants, and pizzerias }\end{array}$ & $\begin{array}{l}\text { Numbers of off-licensed premises (such as } \\
\text { supermarkets) selling alcoholic beverages/100,000 } \\
\text { total population country level }\end{array}$ \\
\hline $\begin{array}{l}\text { Health behavior ( Gual \& Colom, 1997; } \\
\text { Sulkunen, 1989) }\end{array}$ & Smoking rates & $\begin{array}{l}\text { Number of smokers per } 100,000 \text { in the total population } \\
\text { common }\end{array}$ \\
\hline \multirow[t]{3}{*}{$\begin{array}{l}\text { Sociopolitical \& economical major events } \\
\text { (Holder et al., 1998; Moskalewicz \& } \\
\text { Simpura, 2000) }\end{array}$} & Access to the European Union & $\begin{array}{l}\text { Where countries joined the European Union, the year } \\
\text { of access is public knowledge. Where countries are } \\
\text { still separate from the European Union, the year } \\
2001 \text { is indicated common }\end{array}$ \\
\hline & Eastern European transitions & $\begin{array}{l}\text { For countries where this did not apply, the year } 1989 \text { is } \\
\text { taken common }\end{array}$ \\
\hline & Significant political changes & $\begin{array}{l}\text { Year of country's sociopolitical and economical major } \\
\text { events country level }\end{array}$ \\
\hline $\begin{array}{l}\text { Social attitude (Greenfield \& Room, 1997; } \\
\text { Room, Rehm, Trotter, Paglia, \& Üstün, } \\
\text { 2001) }\end{array}$ & Tolerance toward intoxication & High, moderate, low country level \\
\hline Motor road traffic density & Motor vehicles & $\begin{array}{l}\text { (1) Number of motor vehicles } / 100,000 \text { total population } \\
\text { common } \\
\text { (2) Number of trucks, buses, cars, motorcycles, } \\
\text { moped } / 100,000 \text { total population country level. }\end{array}$ \\
\hline \multirow[t]{2}{*}{ Secularization (Michalak et al., 2007) } & $\begin{array}{l}\text { Numbers of people not part of a } \\
\text { religious denomination }\end{array}$ & $\begin{array}{l}\text { Proportion of the population who do not belong to any } \\
\text { traditional religious denomination/100,000 total } \\
\text { population country level }\end{array}$ \\
\hline & $\begin{array}{l}\text { Numbers of people not part of a } \\
\text { religious denomination }\end{array}$ & $\begin{array}{l}\text { Proportion of the population who do not belong to any } \\
\text { religious denomination/100,000 total population } \\
\text { country level }\end{array}$ \\
\hline $\begin{array}{l}\text { Border import of alcoholic beverages } \\
\text { (Anderson, 2009; Holder, 2009) }\end{array}$ & Crossing borders & Cross-border trade country level \\
\hline
\end{tabular}

Note: Common indicators are available for all the countries; country level indicators are only available for 1 or few countries.

[e.g., autoregressive integrated moving average (ARIMA) model].

\section{Statistical Analysis}

The statistical analysis is performed in two steps.

Step 1: Country-Specific Analysis. The aim of this analysis is to examine the temporal trends in the dependent variables that include alcohol consumption and alcohol-consumption-related harm and their relationships with the social, cultural, economical, and demographic factors. The preventive alcohol policies are included for each of the 12 participating countries. This analysis enables the identification of the variables that best explain the trends in alcohol consumption and alcoholconsumption-related harm for each country.

Step 2: Analysis at the European level. Cluster analysis is used to identify mutually exclusive groups of countries on the basis of a similarity or difference in the trends of their variables (Gmel, Rehm, \& Frick, 2001). This permits the identification of groups of homogenous countries in terms of the impact of the independent variables on alcohol consumption and alcohol-consumption-related harm.

Table 4 shows a hypothetical example of the estimated effects of planned and unplanned indicators on the trends in alcohol consumption per capita liters of pure ethanol only based on seven countries.

Figure 3 shows the results in the form of a dendrogram, as an example of cluster analysis, which is based on the fictitious effects of the unplanned indicators shown in Table 4. The dendrogram adopts a threshold of average distance between countries equal to 0.9 , and identifies three clusters of countries: (1) a group including the countries $\mathrm{C} 1, \mathrm{C} 4, \mathrm{C} 5$, and $\mathrm{C} 6$, characterized by a negative association of the mean age and a positive association of smoking rates with alcohol consumption; (2) another group including the countries $\mathrm{C} 2$ and $\mathrm{C} 3$, characterized by a strong positive association of the mean age and educational level with the dependent variable; and (3) the isolated country $\mathrm{C} 7$-a positive low effect of the mean age and employment, and a strong effect of the educational level on alcohol consumption.

In addition to the separate policy effect, we also explore the impact of comprehensiveness of policies in a similar manner.

\section{Limitations}

A weakness of this study is the choice of the determinants and indicators for changes, particularly in the unplanned alcohol consumption. These were decided by the 
TABLE 4. Hypothetical example of the estimated time series effects of planned (preventive alcohol policies) and unplanned (demographic, sociocultural, and economical factors) indicators on alcohol consumption trends (in liters of pure ethanol per capita) across seven countries

\begin{tabular}{|c|c|c|c|c|c|c|c|c|c|}
\hline & & $\mathrm{C} 1$ & $\mathrm{C} 2$ & $\mathrm{C} 3$ & $\mathrm{C} 4$ & C5 & C6 & $\mathrm{C} 7$ & $\begin{array}{c}\text { Pooled } \\
\text { effect }\end{array}$ \\
\hline \multirow[t]{3}{*}{ Planned indicators } & $\begin{array}{l}\text { Increase of BAC limits for } \\
\text { driving }\end{array}$ & & $-0.10^{*}$ & & & $-0.20^{*}$ & & -0.03 & $-0.11^{*}$ \\
\hline & $\begin{array}{l}\text { Introduction of a national } \\
\text { alcohol program }\end{array}$ & & -0.05 & 0.03 & & & $-0.10^{*}$ & & -0.04 \\
\hline & $\begin{array}{l}\text { Reduced opening hours for } \\
\text { bars }\end{array}$ & -0.02 & & & -0.03 & & $-0.04^{*}$ & -0.01 & -0.025 \\
\hline \multirow[t]{5}{*}{ Unplanned indicators } & Mean age & $-0.10^{*}$ & $0.25^{*}$ & $0.25^{* *}$ & $-0.18^{*}$ & -0.02 & $-0.20^{*}$ & 0.05 & $0.11^{*}$ \\
\hline & Educational level & $-0.27^{*}$ & $0.19^{*}$ & $0.11^{*}$ & $0.12^{* *}$ & $-0.17^{*}$ & -0.07 & $0.58^{*}$ & 0.02 \\
\hline & Employment & -0.01 & 0.07 & $0.21^{*}$ & 0.08 & $0.19^{* *}$ & $-0.11^{*}$ & 0.06 & $0.09^{*}$ \\
\hline & Migration inside the country & $0.16^{*}$ & $0.23^{*}$ & $-0.19^{*}$ & $0.19^{* *}$ & -0.02 & 0.01 & $-0.11^{*}$ & -0.01 \\
\hline & Smoking rates & 0.10 & 0.08 & 0.06 & $0.22^{*}$ & $0.17^{*}$ & $0.29^{*}$ & $0.18^{* *}$ & $0.10^{*}$ \\
\hline
\end{tabular}

Note: The superscripts ${ }^{*}$ and ${ }^{* *}$ indicate significance at $5 \%$ and $1 \%$ levels, respectively.

expert panel on the basis of the relevant literature and the potential for being operationalizable across countries. Nonetheless, other important variables might have been overlooked. Moreover, despite the experts carefully discussing each protocol variable, the decision about the indicator operationalization retains the arbitrariness inherent in a consensus procedure.

The study employs a long time frame. Some potentially important variables cannot be included as they may not be accessible or consistently accessible across the five decades. Data might not be homogeneous between countries that have different drinking cultures, different concerns about alcohol-consumption-related problems, different traditions related to alcohol research and prevention policies, and different definitions for the same associated terms.

The study is not the only one based on the assumption that there is a causal relationship between one factor and its outcome, i.e., between alcohol consumption policies and/or the determinants of unplanned change on

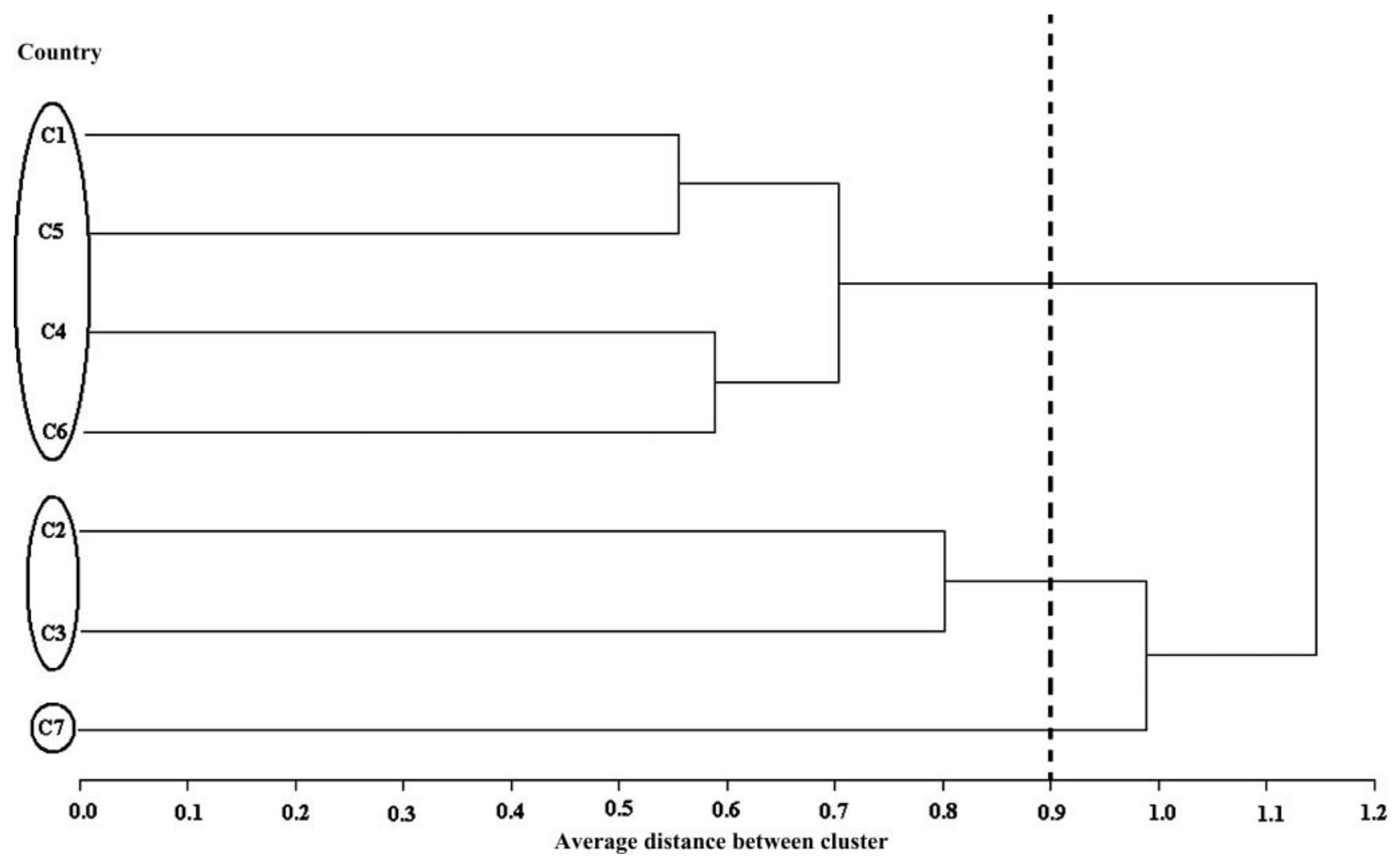

FIGURE 3. Dendrogram of country clusters-factitious example (only unplanned indicators). 
the one hand, and changes in alcohol consumption and alcohol-consumption-related harm on the other hand. In fact, within such a complex phenomenon as alcohol drinking, and its consequences, a single relationship is rarely found (Edwards et al., 1994). Instead, there is a constellation of causes that makes both inference and interpretation a complex task (Rothman, Greenland, Poole, \& Lash, 2008).

\section{WHAT WE EXPECT FROM THIS STUDY}

This study will hopefully make a contribution to science, in terms of its methodology and findings, and to policy, in terms of practical recommendations. Its importance also lies in the fact that Europe is going to face important changes during the next few years that are already having a profound influence on society, for example, globalization, an aging population, and changes in the aspects of work and societal structure.

Although Europeans are getting older, the immigration flux from non-European countries will increase the prevalence of younger groups (European Commission, 2009). Immigrants will probably be more attracted by urban contexts, where conditions of relative anonymity may raise experiences of acculturative stress and tensions between their own and foreign traditions (Berry, 1998). This will further contribute to social inequalities that are connected with cultural stigma and a heavier burden of alcohol-attributable diseases (Room, 2005). At the same time the ideal of consumption, channeled by global market and industry by means of the message that individuals are endowed with free choice and able to decide which goods to purchase among several, may continue to appeal (Sulkunen, Rantala, \& Määttä, 2004).

On the other hand, awareness and concern about one's own health may continue to spread among the population. Contemporary public health expenditure, which in some European countries is as high as $8 \%$ of gross domestic product (Human Development Report, 2008), may continue increasing, with prevention being considered less of a priority for expenditure compared to acute treatments. While the increase in elderly citizens, immigrants, and of globalized consumption patterns may increase the rate of hazardous drinking (Allamani et al., 2009; Hasin, Rahav, Meydan, \& Neumark, 1998; Klein \& Jess, 2002), the raising of health awareness may move in the opposite direction (Tusini, 2007).

From a methodological viewpoint, we assume that this study could provide support to arguments for both researchers and policy-makers. It will enable them to focus on the complexity of alcohol research and to acknowledge the relevance of populations as human social systems that are interacting, adaptive, and creative (Barabasi, 2002; von Foerster, 2002). With this perspective, the health sector should be seen as a part interacting with all the other sectors of society (Holder, 1999) and, whenever possible, the dichotomy or opposition between health and the other sectors in society should be reduced (Warner \&
White, 2003). The risk of consuming alcohol might be conceptualized and faced as an alternative to other risk taking behaviors and contexts (Büringer, 2004; WHO, 2001).

From a practical perspective, our study findings could suggest that the effectiveness of preventive interventions may be substantially improved if positive contextual factors are taken into account when planning any policy. This would also help to address the increasing limitations on health budgets (Giesbrecht, 2007) and could provide information on the health impact of different governmental initiatives (WHO, 2000). Clearly, a better understanding of the perceptions and opinions of the general population on the health issues related to alcohol (Greenfield \& Room, 1997; Nordlund, 2008) is required.

In conclusion, we purport that, when available, the findings of this study will provide recommendations to policymakers and public health experts to incorporate a contextual approach into their alcohol consumption prevention policies. They will also add to the body of knowledge relating to understanding the ongoing changes in alcohol consumption. This should place policy-makers and public health experts to be in a better position to identify the best cost-effective measures to be adopted in order to reduce alcohol-consumption-related harm.

\section{Declaration of Interest}

The authors report no conflicts of interest. The authors alone are responsible for the content and writing of the article.

\section{RESUME}

Déterminants contextuels de la consommation d'alcool et de l'évolution des politiques de prévention alcool. Une étude européenne de 12 pays en cours.

Dans les années 50 la consommation d'alcool dans le sud de pays européens (France compris) a diminué, en particulier elle a baisse' avec peu ou pas de mesures préventives en matière d'alcool, tandis que la consommation d'alcool a augmenté dans les pays nordiques où, historiquement, étaient en place les politiques de contrôle de l'alcool plus restrictives, même si, plus récemment, elles ont été assouplies. Au même temps, l'Europe centrale et orientale ont montré un comportement intermédiaire. Cela nous a proposé que les modifications spécifiques à chaque pays dans la consommation d'alcool entre 1960-2008 sont expliquées par une combinaison d'un certain nombre de facteurs: (a) les politiques de prévention de l'alcool, et (b) les déterminants sociaux, culturels, économiques et démographiques. Ce document décrit la méthodologie d'une étude de recherche visant à comprendre les interactions complexes, qui ont eu lieu dans toute l'Europe au cours des cinq dernières décennies. Il s'agit notamment des changements dans la consommation d'alcool, dans les habitudes de consommation et dans les méfaits liés à l'alcool, et les déterminants réels de tels changements. 


\section{RESUMEN}

\section{Determinantes contextuales de los cambios en el consumo de alcohol y políticas preventivas en el ámbito del alcohol}

El consumo de alcohol en el sur de Europa ha decrecido desde la década de los 50, empezando por Francia, aunque poca o ninguna medida preventiva se hubiera implementado en dichos países. En cambio, simultáneamente el consumo de alcohol experimentó un incremento en los países nórdicos, donde existe una tradición histórica de políticas mas restrictivas, aunque recientemente hayan sido atenuadas. Al mismo tiempo, la Europa Central y del Este ha mostrado comportamientos intermedios. Proponemos que los cambios específicos experimentados por los países europeos en el periodo 1960-2008 pueden explicarse por la combinación de un conjunto de factores: (a) políticas preventivas en el ámbito del alcohol, y (b) determinantes sociales, culturales económicos y demográficos. Este artículo describe la metodología de un trabajo de investigación diseñado para entender las complejas interacciones que han ocurrido en Europa durante las últimas cinco décadas, incluyendo los cambios en las cantidades de alcohol consumidas, los patrones de consumo los trastornos relacionados con el alcohol y los determinantes de dichos cambios.

\section{THE AUTHORS}

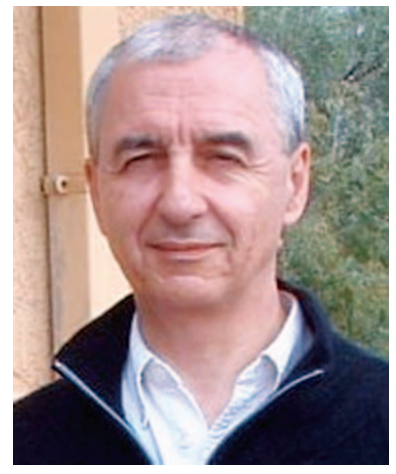

Allaman Allamani, M.D., Psychiatrist, Coordinator of Centro Alcologico, Florence Health Agency (1993-2009). He is a consultant of Region of Tuscany Health Agency and a member of the Institute of Psychosomatic Education, Florence. He has been the coordinator of some Italian alcohol community and prevention projects and has been involved in a few European alcohol prevention projects. He is also a member of the Editorial Board of Substance Use and Misuse, and author or co-author of over 170 articles and editor/co-editor of 16 books. He is a work package 3 leader of the AMPHORA project.

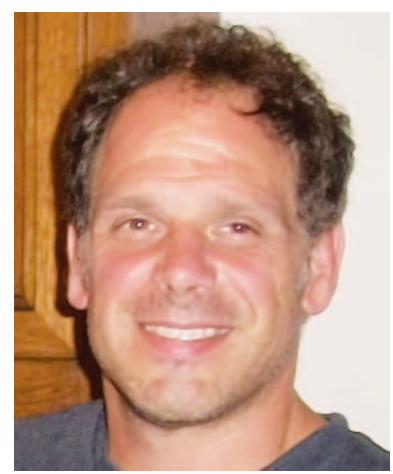

Fabio Voller, Ph.D., is a Sociologist at the Epidemiology Observatory of the Region of Tuscany Health Agency. He has worked on epidemiological studies of lifestyle, alcohol consumption, and psychoactive drug use in the Tuscan population. Among his publications, he is the co-author of a number of monographs about the health consequences of alcohol consumption in Italy. He is a work package 3 leader of the AMPHORA project.

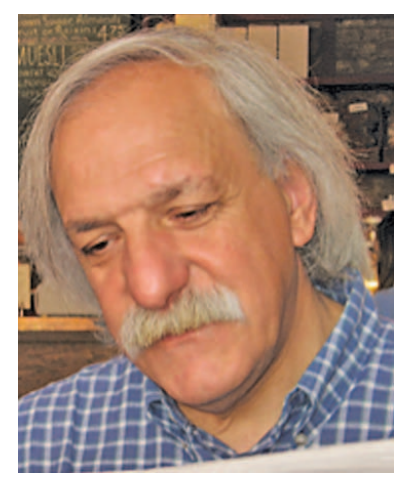

Adriano Decarli, Ph.D., is a full-time Professor in medical statistics, Director of Medical Statistics and Biometry Section at the University of Milan, Head of Medical Statistics and Biometry Unit, IRCCS/INT Foundation in Milan. He is the Principal Investigator of epidemiological and methodological research projects on the role of dietary habits, hormones, and familial factors as determinants of chronic diseases in Italy and on the influence of the modifiable risk factors on the individual probability of cancer developing. He is the President of the Italian Biometric Society, Former President of SISMEC (Italian Society of Medical Statistics and Clinical Epidemiology), reviewer of several scientific journals, and author/co-author of more than 350 scientific publications (275 indexed in PubMed/Medline).

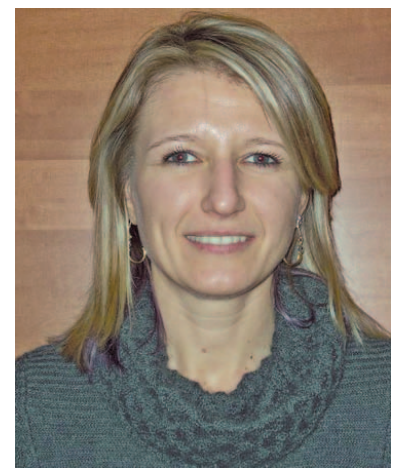

Veronica Casotto is a Researcher at the Epidemiology Observatory of the Regional Health Agency of Tuscany. She is a statistician and she has a master's degree in epidemiology. She has several years of experience in biostatistics and epidemiology, which has been applied to study planning, research design, database management, and data analysis.

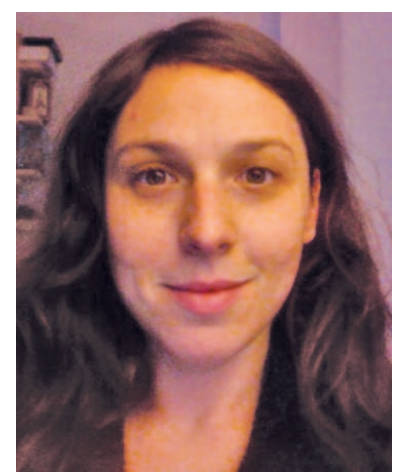

Sanità (ARS, Italy).

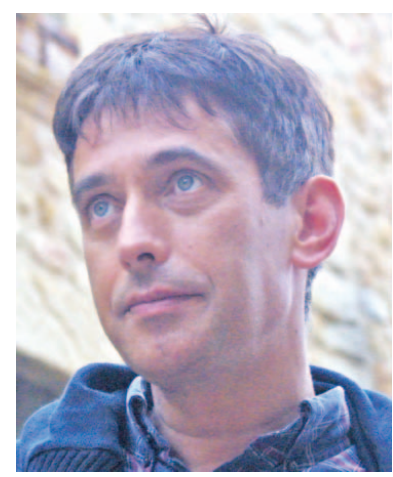

Karin Pantzer, M.P.H., graduated in sociology, M.P.H. at the Pompeu Fabra University in Barcelona, and postgraduated in medical anthropology at the Milano-Bicocca University. She worked as a researcher for the Public Health Agency of Barcelona, for the Catalan Agency for Health Technology Assessment, the National Institutes of Health (NIH, USA), and for the Agenzia Regionale di

Peter Anderson, M.D., M.P.H., Ph.D., F.R.C.P., is a Professor at the Faculty of Health, Medicine and Life Sciences, Maastricht University, the Netherlands, and a Visiting Professor at the Institute of Health and Society, Newcastle University, England. He coordinates several major international research and policy projects for addictions and mental health for the European Commission and the World 
Health Organization. He has over 120 publications in international peer-reviewed journals and is the author or editor of some 15 books. He has authored many monographs for the European Commission and the World Health Organization.

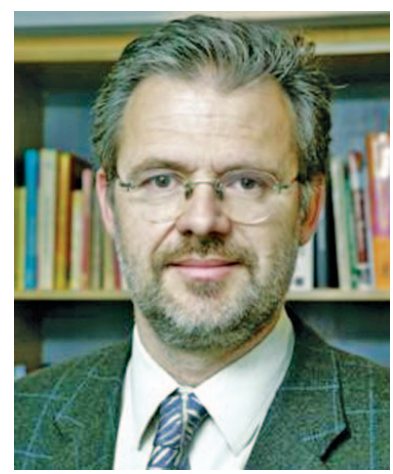

Antoni Gual is a Psychiatrist, with a long experience in alcohol research, including both the clinical and the public health fields. He conducts the alcohol unit at the Clinic Hospital of Barcelona, Spain, and also acts as an alcohol consultant at the Health Department of Catalonia. He is the coordinator of the Amphora project and is involved in several European research projects in the areas of public health and clinical trials. He is the Vice President of the International Network on Brief Interventions for Alcohol Problems (INEBRIA), research officer of the European Federation of Addiction Scientific Societies (EUFAS), and former president of the Spanish Scientific Society for the study of alcohol and alcoholism.

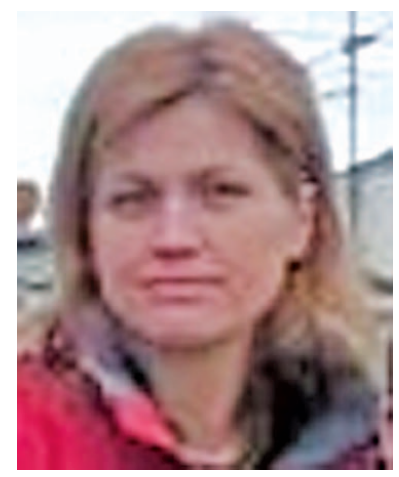

Silvia Matrai is a Psychologist and masters in cognitivebehavioral therapy, psychopathology, and health care management, Barcelona, Spain. She has experience as a clinical psychologist in different health settings, including medical inpatients, prepartum and postpartum psychopathology, cancer patients, and addictions, and also in clinical research. She has several publications in scientific journals and is the external advisor of Médecins Sans Frontières on mentalh-health-related issues.

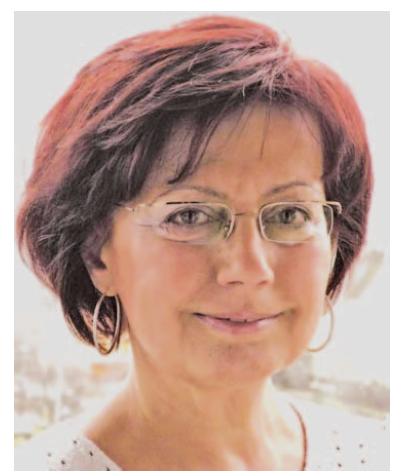

Zsuzsanna Elekes, Ph.D., is a full-time Associate Professor at the Institute of Sociology and Social Policy, Corvinus University of Budapest. Her research activities mainly focus on alcohol and drug epidemiology and social policy. She has participated in several international projects in these fields.

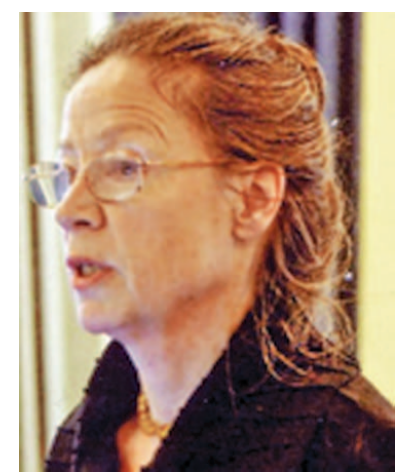

Irmgard Eisenbach-Stangl is a Professor, a Sociologist, and a Psychotherapist, with long experiences in alcohol and drug research. She participated in several international comparative studies on alcohol consumption, alcohol policy, and alcohol prevention in European countries. She has worked for many years as a member of the advisory boards for measures against alcohol misuse and misuse of other addictive substances at the Austrian Federal Ministry of Health, for WHO Europe and WHO in Geneva and for the European Commission. Currently, she works as a senior researcher at the European Centre for Social Welfare Policy and Research in Vienna and is the lead researcher for the research area "alcohol, drugs, addiction."

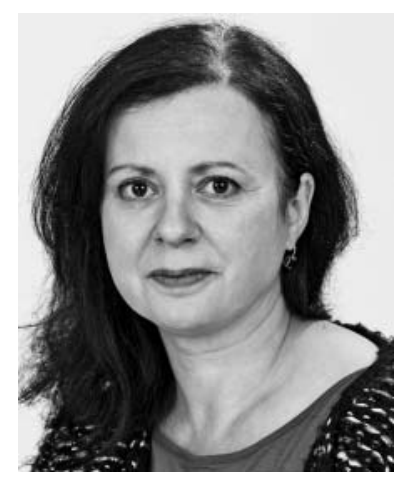

Gabriele Schmied, master of sociology (University of Vienna), acts as a Social Scientist since 1990. Since 2000, she is working at the European Centre as a researcher in the area of health and care (former health and welfare). She was involved in several national and international research projects in the field of health promotion and prevention, with a focus on HIV and alcohol and drugs research.

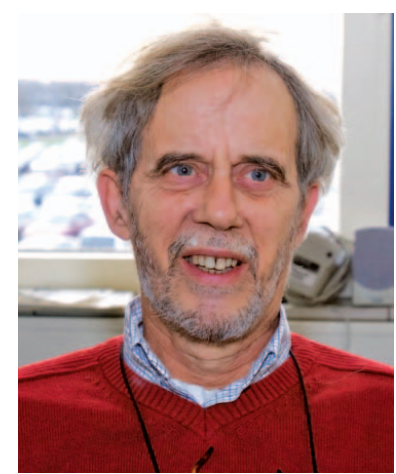

Ronald A. Knibbe, Ph.D., works as a Professor of the social epidemiology of alcohol and drug use at the Health Promotion Department of the Faculty of Health, Medical, and Life Sciences, Maastricht University. His main interests include adolescent and young adult's alcohol consumption, marginalized drug users, and cross-cultural comparisons of alcohol and drug use.

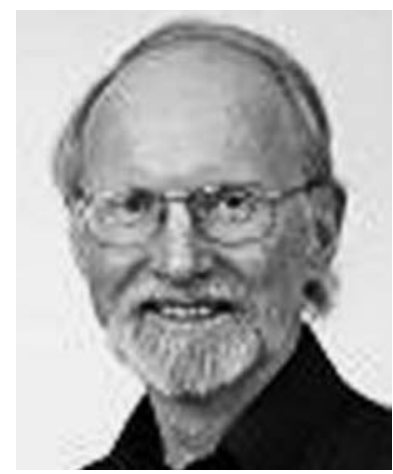

Sturla Nordlund, Senior Scientist, Former Director and Research Director of the Norwegian Institute for Alcohol and Drug Research (SIRUS), is a Statistician with a very long experience in social alcohol research. He has been the leader of several research projects and is now leading a work package in the Amphora project. 


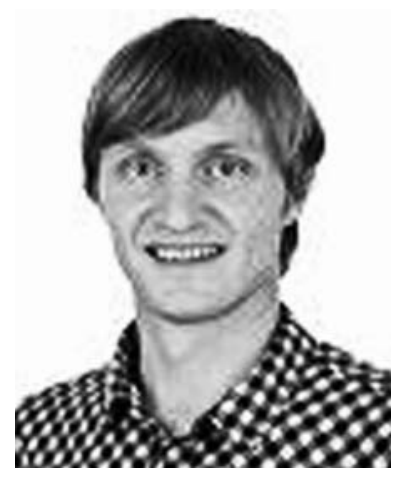

Øystein Skjælaaen is a

Criminologist with experience in research on alcohol and illegal drugs. He works as an advisor at the Norwegian Institute for Alcohol and Drug Research, and is soon to start a Ph.D. project focusing on the cultural aspects of alcohol use in Norway.

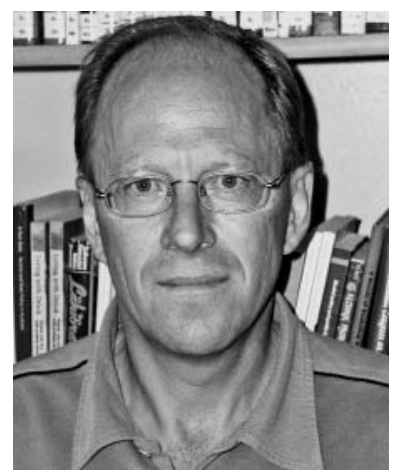

Börje Olsson, Ph.D. in sociology, is a full-time Professor at the Centre for Social Research on Alcohol and Drugs (SoRAD), Stockholm University. His primary research areas during the last 10 years are drug use and control policies in an international perspective, cultural perspectives on alcohol, drug use and prevention, public opinion, and media representations of alcohol and drug problems. Previous research areas include epidemiology and treatment research.

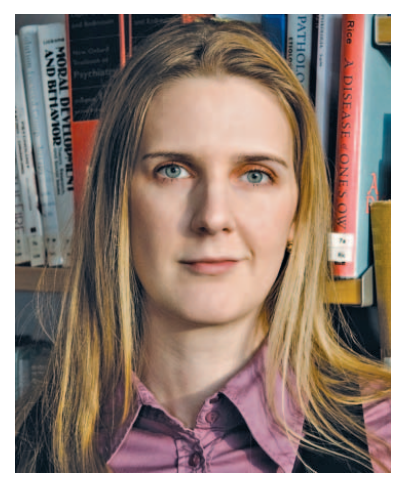

Jenny Cisneros Örnberg, $\mathrm{Ph} . \mathrm{D}$. in political science and a researcher and Deputy Director of SoRAD. Her research covers the policy development of public-health-related questions in Sweden and on a European Union level.

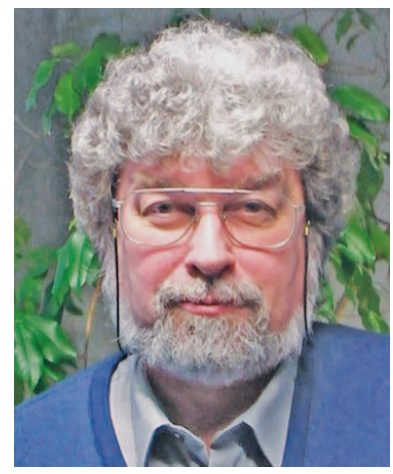

Esa Österberg, MSc, works as a Senior Researcher at the National Institute for Health and Welfare in Finland. He is a member of the Alcohol and Public Policy Group, which produced the monographs Alcohol Policy and the Public Good in 1994 and Alcohol—No Ordinary Commodity first edition in 2003 and second edition in 2010.

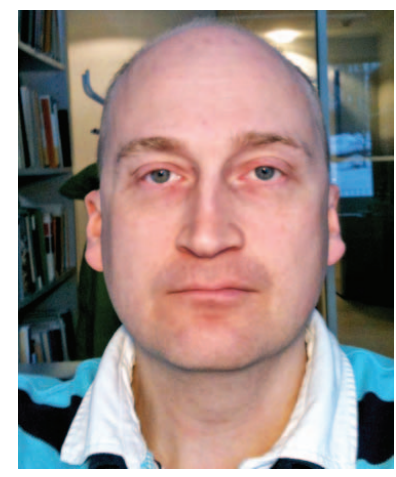

Thomas G. Karlsson, MSc, is a Researcher at the Department of Alcohol, Drugs and Addiction at the National Institute for Health and Welfare (THL). He has been active in the field of alcohol research since 1995 and has participated in several international research projects co-funded by the European Commission. These are, for instance, the European Comparative Alcohol Study

(ECAS) as well as the SMART and AMPHORA projects. Karlsson is also a member of the Editorial Board of the scientific journal Nordic Studies of Alcohol and Drugs.

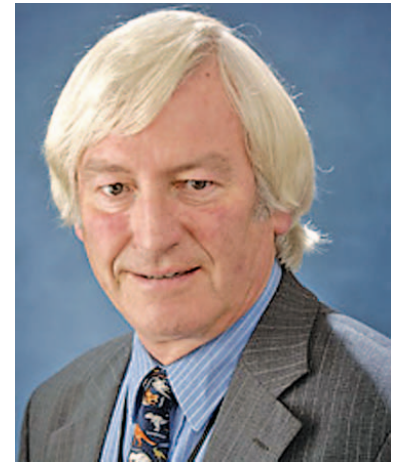

Martin Plant, Ph.D., was a Professor of addiction studies at the University of the West of England Bristol. He was engaged in a research into alcohol and other drugs since 1970. His work focused on issues related to alcohol and allied themes. He carried out a series of social and behavioral studies related to alcohol and other drugs. In addition, he conducted studies of HIV/AIDS

risks in relation to the sex industry and alcohol and drug problems among anesthetists and the mental health needs of prison inmates. One of his main areas of interest was harm minimization and prevention policy. Until his death in March 2010, Martin was the Director of the UK part of a 36-country collaborative study, the European School Survey Project on Alcohol \& other Drugs (ESPAD). He produced over 250 publications including a number of books. He served as a World Health Organization consultant, and an advisor to a number of UK and overseas government departments.

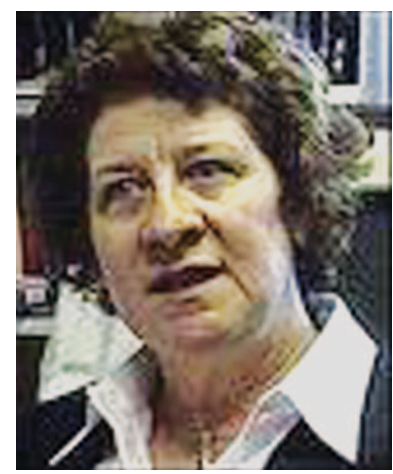

Moira Plant is a Professor of alcohol studies at the University of the West of England Bristol. Her work has mainly focused on issues related to alcohol and gender- and alcoholrelated foetal harm. In addition, she has conducted studies of HIV/AIDS risks in relation to the sex industry, nurses and stress, and alcohol and drug problems among anesthetists and the mental health needs of prison inmates. She is the Director of the UK part of a 36country collaborative study, Gender, Alcohol and Culture: An International Study (GENACIS). She has published a number of books; the latest written in collaboration with Professor Martin Plant is Binge Britain (2006). She has acted as a government advisor on issues such as women and alcohol and drinking in pregnancy. 


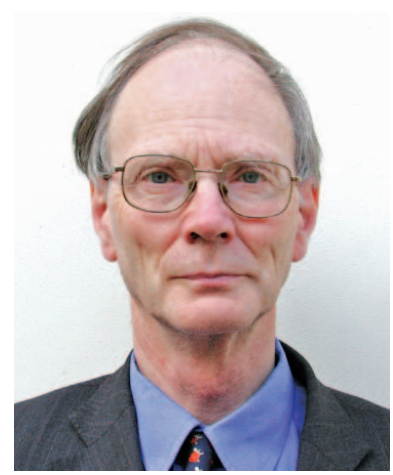

Patrick Miller is a retired Senior Research Fellow at the University of the West of England, with interests in survey work on drugs, alcohol, depression, and life events.

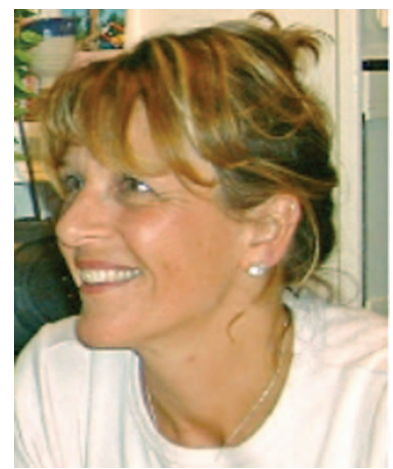

Nikki Coghill, Ph.D., M.Sc., B.Sc., is a Senior Research Fellow in the Alcohol and Health Research Unit at the University of the West of England. She is an experienced alcohol-related researcher, with a particular interest in public health. She is involved in several national and international alcohol-related research projects.

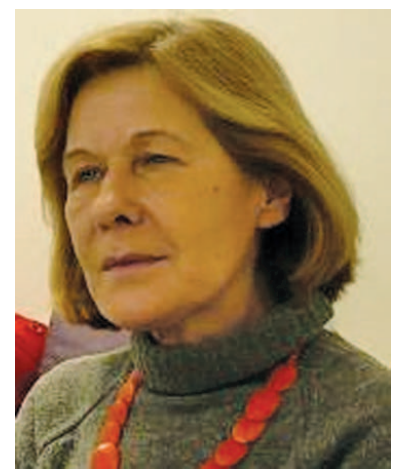

Grażyna Światkiewicz is a Psychologist and Sociologist with a long experience in alcohol and drug research. She is an Assistant Professor at the Institute of Psychiatry and Neurology and participant and/or coordinator in many Polish and international research projects. She has been the author of more than 100 publications in Polish and international journals and books. Publications deal mainly with sociocultural contexts of psychoactive substances consumption and related problems.

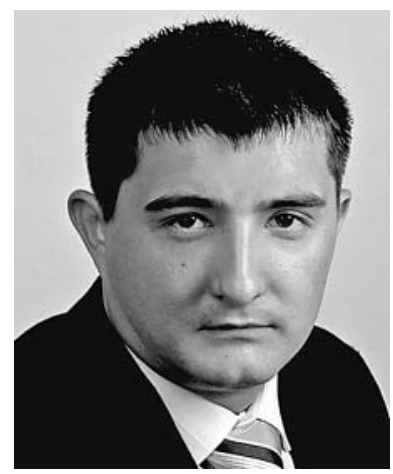

Lukasz Wieczorek is a fourth year doctoral student at the Department of Studies on Alcohol and Drug Dependence, Institute of Psychiatry and Neurology in Warsaw. His doctoral thesis concerns the barriers and facilitations of access to alcohol treatment, stigmatization of patients receiving alcohol treatment, and role of institution in treatment. His research interest focuses on epidemiology of addiction, policy on psychoactive substance, and alcohol and drug treatment system.

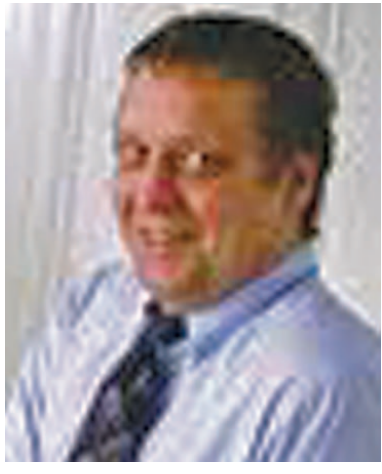

Gerhard Gmel, Ph.D., is associated with the Addiction Info Switzerland, Alcohol Treatment Centre, Lausanne University Hospital. Trained as a psychologist, he now works as an epidemiologist mainly in two domains. First, he is involved in many international research projects using survey data. For example, he is currently the centralized analysis and databank coordinator of one of the major research projects on gender and alcohol (GenACIS) including surveys from more than 40 counties all over the world, and participated in international youth projects such as ESPAD. He just started a cohort study with a 19-year-old man to follow-up their substance use patterns and related consequences. Second, he is doing emergency department studies and testing of the effectiveness of brief interventions in different settings. He is also a temporary advisor of the WHO with regard to alcohol epidemiology and policy and collaborated with the WHO on the estimation of the Global Burden of Disease 2000 and 2010 stemming from alcohol use, and senior editor of Addiction.

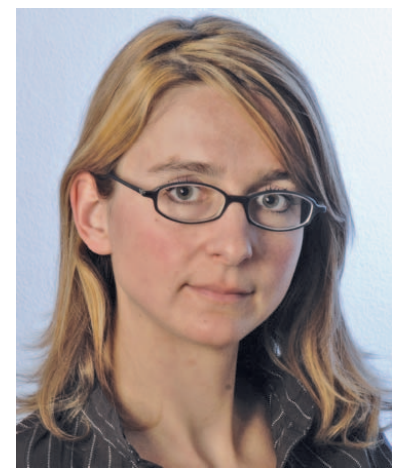

Beatrice Annaheim is a Sociologist, active in addiction research, with a main focus on cannabis use, substance use, and sports, as well as on the evaluation of prevention projects. Since 2009, she has been collaborating in the AMPHORA project on behalf of Addiction Info Switzerland.

\section{GLOSSARY}

Alcohol consumption: It may be integrated into a society's daily life, or it may be perceived as a social and health problem.

Alcohol policies: These are planned by governments to control the supply and demand of alcoholic beverages, aiming at minimizing alcohol-consumptionrelated problems.

Time trend: A period of time, during which changes in consumption occur.

Unplanned determinants of consumption changes: A number of social, cultural, economic, and demographic factors that are not planned by governments and health authorities, but that may affect consumption and drinking patterns.

\section{REFERENCES}

Admunsen, E. J., Rossow, I., \& Skurtveit, S. (2005). Drinking pattern among adolescents with immigrant and Norwegian background: A two-way influence? Addiction, 100(10), 1453-1463.

Allamani, A., Cipriani, F., Voller, F., Rossi, D., Anav, S., Karlsson, T., et al. (2002). Italy. In E. Österberg \& T. Karlsson (Eds.), 
Alcohol policies in EU member states and Norway (pp. 258-284). National Research and Development Centre for Welfare and Health (STAKES). Saarijärvi, Finland: Gummerus Printing.

Allamani, A., Innocenti, F. B., Innocenti, A., Cipriani, F., \& Voller, F. (2009). Alcohol and tobacco consumption among Albanian immigrants in Florence. Substance Use \& Misuse, 44(2), 282-300.

Allamani, A., \& Prina, F. (2007). Why the decrease in consumption of alcoholic beverages in Italy between the 1970s and the 2000s? Shedding light on an Italian mystery. Contemporary Drug Problems, 34, 187-197.

Anderson, P. (2009). Evidence for the effectiveness and costeffectiveness of interventions to reduce alcohol-related harm. Copenhagen: World Health Organization Regional Office for Europe.

Anderson, P., \& Baumberg, B. (2005). Alcohol in Europe. A report for the European Commission. London: Institute of Alcohol Studies.

Babor, T. F., Caetano, R., Casswell, S., Edwards, G., Giesbrecht, N., Graham, K., et al. (2003). Alcohol: No ordinary commodity. Oxford: Oxford University Press.

Barabasi, A. L. (2002). Linked: How everything is connected to everything else and what it means. New York: Penguin.

Berry, J. W. (1998). Acculturative stress. In P. B. Organista, K. M. Chun, \& G. Marin (Eds.), Readings in ethnic psychology (pp. 117-122). New York: Routledge.

Brand, A. D., Saisana, M., Rynn, L. Q., Pennoni, F., \& Lowenfels, A. B. (2007). Comparative analysis of alcohol control policies in 30 countries. PLoS Medicine, 4(4), e151.

Bruun, K., Edwards, G., Lumio, M., Mäkelä, K., Pan, L., Popham, R. E., et al. (1975). Alcohol control policies in public health perspective. Helsinki: Finnish Foundation for Alcohol Studies.

Büringer, G. (2004). Don't cover up distinct responsibilities ù, but co-operate on the action level under certain conditions. Addiction, 99, 1379-1380.

Cipriani, F. (2007). Temporal trends in wine and food consumption in Italy. Contemporary Drug Problems, 34, 227-243.

Cipriani, F., \& Tusini, (2007). A demographic interpretation of the decrease in alcohol consumption in Italy. Contemporary Drug Problems, 34, 245-252.

Craplet, M. (2006). Open letter to my friend and colleagues. Addiction, 101, 450-452.

Currie, C., Roberts, C., Morgan, A., Smith, R., Settertobulte, W., Samdal, O., et al. (2004). Health Behaviour in School-aged Children (HBSC). Copenhagen: WHO Regional Office for Europe.

Edwards, G., Anderson, P., Babor, T., Casswell, S., Ferrence, R., Giesbrecht, N., et al. (1994). Alcohol policy and the public good. Oxford: Oxford University Press.

European Commission. (2009). Europe's changing population structure and its impact on relations between the generations. Retrieved February 2010, from http://europa.eu/rapid/pressReleasesAction.do?reference

Giesbrecht, N. (2007). Community-based prevention of alcohol problems: Addressing the challenges of increasing deregulation of alcohol. Substance Use \& Misuse, 42, 1813-1834.

Gmel, G., Rehm, J., \& Frick, U. (2001). Methodological approach to conducting pooled-cross-sectional time series analysis: The example of the association between all-cause mortality and per capita alcohol consumption for men in 15 European states. European Addition Research, 7, 128-137.

Grant, M. (Ed.). (1985). Alcohol policies (European Series No. 18). Copenhagen: WHO Regional Publications.

Greenfield, T., \& Room, R. (1997). Situational norms for drinking and drunkenness: Trends in the US adult population, 1979-1990. Addiction, 92, 33-47.
Gruenewald, P. J., Remer, L., \& Lipton, R. (2002). Evaluating the alcohol environment: Community geography and alcohol problems. Alcohol Research and Health, 26(1), 42-48.

Gual, A., \& Colom, J. (1997). Why has alcohol consumption declined in countries of Southern Europe? Addiction, 92(1 Suppl.), S21-S31.

Hasin, D., Rahav, G., Meydan, J., \& Neumark, Y. (1998). The drinking of earlier and more recent Russian immigrants to Israel: Comparison to other Israelis. Journal of Substance Abuse, 10, 341-353.

Heath, D. B. (Ed.). (1995). International handbook on alcohol and culture (pp. 230-234). Westport, CT: Greenwood Press.

Heather, N. (2006). Britain's alcohol problem and what the UK government is (and is not) doing about it. Addiciones, 18(3), 225-235.

Hibell, B., Guttormsson, U., Ahlström, S., Balakireva, O., Bjarnason, T., Kokkevi, A., et al. (2009). The 2007 ESPAD report. Substance use among students in 35 European countries. The Swedish Council for Information on Alcohol and Other Drugs (CAN), The European Monitoring Centre for Drugs and Drug Addiction (EMCDDA), and the Pompidou Group at the Council of Europe. Stockholm: Modintryckoffsett AB.

Hill, A. B. (1965). The environment and disease: Associations or causation? Proceedings of the Royal Society of Medicine, 58, 295-300.

Holder, H., Kühlhorn, E., Nordlund, S., Österberg, E., Romelsjö, A., \& Ugland, T. (1998). European integration and Nordic alcohol policies. Aldershot: Ashgate.

Holder, H. D. (1999). Alcohol and the community. Cambridge: University Press.

Holder, H. D. (2000). Overall changes and consequences in alcohol use and problems and prospects for the future in Sweden. In H. D. Holder (Ed.), Sweden and the European Union (p. 262). The Swedish Alcohol Retailing Monopoly and the National Institute of Public Health. Stockholm: Almqvist \& Wiksell International.

Holder, H. D. (2009). Border trade and private import in Nordic countries. Implications for alcohol policy. Nordoic Studies on Alcohol and Drugs, 26, 232-236.

Holder, H. D., Gruenewald, P. J., Ponicki, W. R., Treno, A. J., Grube, J. W., Saltz, R. F., et al. (2000). Effect of communitybased interventions on high-risk drinking and alcohol-related injuries. Journal of American Medical Association, 284(18), 2341-2347.

Holmila, M. (1997). Community prevention of alcohol problems. Ipswich: WHO McMillan.

Human Development Report. (2008). Commitment to health: Resources, access and services. Retrieved February 2010, from http://hdrstats.undp.org/indicators/50.html

Hupkens, C. L. H., Knibbe, R. A., \& Drop, M. J. (1993). Alcohol consumption in the European community: Uniformity and diversity in drinking patterns. Addiction, 88, 1391-1404.

Karlsson, T., \& Österberg, E. (2001). A scale of formal alcohol control policy in 15 European countries. Nordic Studies on Alcohol and Drugs (English Supplement), 18, 117-131.

Klein, W. C., \& Jess, C. (2002). One last pleasure? Alcohol use among elderly people in nursing homes. Health and Social Work, 27(3), 193-203.

Knibbe, R. A., Drop, M. J., \& Hupkens, C. L. H. (1996). Modernization and geographical diffusion as explanations for regional differences in the consumption of wine and beer in the European community. Substance Use \& Misuse, 31(11-12), 1639-1655.

König, C., \& Segura, L. (2011). Do infrastructures impact on alcohol policy making? Addiction, 106(Suppl. 1), 47-54.

Leifman, H. (2001). Homogenisation in alcohol consumption in the European Union. Nordic Studies on Alcohol and Drug (English Supplement), 18, 15-30. 
Leifman, H. (2002). Trends in population drinking. In T. Norström (Ed.), Alcohol in postwar Europe: Consumption, drinking patterns, consequences and policy responses in 15 European countries (pp. 49-81). National Institute of Public Health. Stockholm: Almqvist \& Wiksell.

Mäkelä, K., Room, R., Singel, E., Sulkunen, P., \& Walsh, B. (1981). Alcohol, society and the state. A comparative study of alcohol control. Toronto, ON: Addiction Research Foundation.

Michalak, L., Trocki, K., \& Bond, J. (2007). Religion and alcohol in the US National Alcohol Survey: How important is religion for abstension and drinking? Drug and Alcohol Dependence, 87, 268-280.

Moskalewicz, J., \& Simpura, J. (2000). The supply of alcoholic beverages in transitional conditions: The case of Central and Eastern Europe. Addiction, 95(4 Suppl.), S505-S522.

Munro, G. (2004). An addiction agency's collaboration with the drinks industry: Moo Joose as a case study. Addiction, 99, 1170-1174.

Nordlund, S. (2008). What is alcohol abuse? Changes in Norwegians' perceptions of drinking practices since the 1960s. Addiction Research and Theory, 16, 85-94.

Norström, T. (Ed.). (2002). Alcohol in postwar Europe: Consumption, drinking patterns, consequences and policy responses in 15 European countries. National Institute of Public Health. Stockholm: Almqvist \& Wiksell.

Olsson, B., Olafsdottir, H., \& Room, R. (2002). Nordic tradition of studying the impact of alcohol problems. In R. Room (Ed.), The effect of Nordic alcohol policies (pp. 5-16). Helsinki: NAD Publications (No. 42)

Österberg, E., \& Karlsson, T. (Eds.). (2002a). Alcohol policies in EU member states and Norway. Helsinki: STAKES.

Österberg, E., \& Karlsson, T. (2002b). Alcohol policies in the ECAS countries, 1950-2000. In T. Norström (Ed.), Alcohol in postwar Europe: Consumption, drinking patterns, consequences and policy responses in 15 European countries (pp. 11-48). National Institute of Public Health. Stockholm: Almqvist \& Wiksell

Plant, M., \& Plant, M. (2006). Binge Britain. Alcohol and the national response. Oxford: Oxford University Press.

Pridemore, W. A., \& Snowden, A. J. (2009). Reduction in suicide mortality following a New National Alcohol Policy in Slovena: An interrupted time-series analysis. American Journal of Public Health, 99(5), 915-920.

Productshap Voor Gedistillerde Dranken. (2005). World drink trends. Henley-on-Thames: NTC Publications.

Ramstedt, M. (2002). Alcohol-related mortality in 15 European countries in the post-war period. In T. Norström (Ed.), Alcohol in postwar Europe: Consumption, drinking patterns, consequences and policy responses in 15 European countries (pp. 137-156). National Institute of Public Health. Stockholm: Almqvist \& Wiksell.

Rehm, J., Room, R., Monteiro, M., Gmel, G., Graham, K., Rehn, N., et al. (2003). Alcohol as a risk factor for global burden of disease. European Addiction Research, 9, 157-164.

Rehm, J., \& Scafato, E. (2011). Indicators of alcohol consumption and attributable harm for monitoring and surveillance in European Union countries. Addiction, 106(Suppl. 1), 4-10.

Room, R. (1992). The impossible dream. Routes to reducing alcohol problems in a temperance culture. Journal of Substance Use, 4, 91-106.

Room, R. (1999). The idea of alcohol policy. Nordic Studies on Alcohol and Drugs (English Supplement), 16, S7-S20.

Room, R. (2002a). A hazardous commodity with culture bound effects: Policy implications of ECAS. In T. Norström (Ed.), Alcohol in postwar Europe: Consumption, drinking patterns, consequences and policy responses in 15 European countries (pp. 23-219). National Institute of Public Health. Stockholm: Almqvist \& Wiksell.

Room, R. (Ed.). (2002b). The effects of Nordic alcohol policies. Helsinki: NAD Publications.

Room, R. (2005). Stigma, social inequities and alcohol and drug use. Drug and Alcohol Review, 24, 143-155.

Room, R., Babor, T., \& Rehm, J. (2005). Alcohol and public health. Lancet, 365, 519-530.

Room, R., \& Mäkelä, K. (2000). Typologies and the cultural position of drinking. Journal of Studies on Alcohol, 61, 475-483.

Room, R., Rehm, J., Trotter, R. T., Paglia, A., \& Üstün, T. B. (2001). Cross-cultural views on stigma, valuation, parity and societal attitudes towards disability. In T. B. Üstün, S. Chatterji, J. E. Bickenbach, R. T. Trotter, R. Room, J. Rehmet al. (Eds.), Disability and culture: Universalism and diversity (pp. 247-291). Seattle, WA: Hofgrebe and Huber.

Rothman, K. J., Greenland, S., Poole, C., \& Lash, T. L. (2008). Causation and causal inference. In K. J. Rothman, S. Greenland, \& T. L. Lash (Eds.), Modern epidemiology (pp. 5-31). Philadelphia, PA: Lippincott Williams \& Wilkins.

Simpura, J. (1998). Mediterranean mysteries: Mechanisms of declining alcohol consumption. Addiction, 93(9), 1301-1304.

Simpura, J., Karlsson, T., \& Leppänen, K. (2002). European trends in drinking patterns and their socio-economic background. In T. Norström (Ed.), Alcohol in postwar Europe: Consumption, drinking patterns, consequences and policy responses in 15 European countries (pp. 83-114). National Institute of Public Health. Stockholm: Almqvist \& Wiksell.

Sulkunen, P. (1989). Drinking in France, 1965-1979. An analysis of household consumption data. British Journal of Addiction, 84, 61-72.

Sulkunen, P., Rantala, K., \& Määttä, M. (2004). The ethics of not taking a stand: Dilemmas of drug and alcohol prevention in a consumer society-A case study. International Journal of Drug Policy, 15(5), 427-434.

Sulkunen, P., Sutton, C., Tigerstedt, C., \& Warpenius, C. (2000). Broken spirits. Hakapaino Oy, Helsinki: NAD Publication (No. 39).

Tusini, S. (2007). The decrease in alcohol consumption in Italy: Sociological interpretations. Contemporary Drug Problems, 34, 253-285.

von Foerster, H. (2002). Understanding Understanding: Essays on cybernetics and cognition. New York: Springer-Verlag.

Wagenaar, A. C. (1986). Preventing highway crashes by raising the minimal age for drinking: The Michigan experience 6 years later. Journal of Safety Research, 17, 101-109.

Warner, L. A., \& White, H. R. (2003). Longitudinal effects of age at onset and first drinking situation on problem drinking. Substance Use \& Misuse, 38(14), 1983-2016.

World Health Organization. (1992). European Alcohol Action Plan (Document EUR/RC42/8). Copenhagen: World Health Organization Regional Office for Europe.

World Health Organization. (2000). Health impact assessment: Comparative quantification of mortality and burden of disease attributable to selected risk factors. In WHO regional office for Europe (Ed.), Global burden of disease and risk factors. Copenhagen: Author.

World Health Organization. (2001). Declaration on Young People and Alcohol. Copenhagen: World Health Organization Regional Office for Europe.

World Health Organization. (2009). European Health for All Database (HFA-DB). Copenhagen: WHO Regional Office for Europe. Retrieved February 2010, from http://www.euro. who.int/hfadb 
Copyright of Substance Use \& Misuse is the property of Taylor \& Francis Ltd and its content may not be copied or emailed to multiple sites or posted to a listserv without the copyright holder's express written permission. However, users may print, download, or email articles for individual use. 
Copyright of Substance Use \& Misuse is the property of Taylor \& Francis Ltd and its content may not be copied or emailed to multiple sites or posted to a listserv without the copyright holder's express written permission. However, users may print, download, or email articles for individual use. 